\title{
Digital Media Unequality During the 2014th Indonesian Presidential Election
}

\author{
Hedi Pudjo Santosa ${ }^{1 *}$, Nurul Hasfi ${ }^{1}$, Triyono Lukmantoro ${ }^{1}$ \\ ${ }^{1}$ Department of Communication, Faculty of Social and Political Science, Diponegoro University, Semarang
}

\begin{abstract}
In the internet era, a hoax is a real threat for democracy, as it spreads misleading and fake information that creats uncertain political communication. During the 2014 Indonesian presidential election, a hoax was rapidly spreading thorough social media. Morover, in Indonesian political context, a hoax construct strategically by using primordialism issue. This study uses critical discourse analysis to identify a pattern of hoax during the 2014 Indonesian presidential election, particularly to show how primordialism constructs an unequel society. The data was taken from political discussion among 8 influential Twitter accounts, two months before the election. The study found that 1) A hoax was produced by using many techniques; 2) Mainstream 'online media' involved in the production of the hoax, particularly by constructing sensational headline. Meanwhile, fake news commonly produced and distributed by pseudonym Twitter accounts; 3) Both hoax and fake news generally run under a mechanism of primordialism issue.
\end{abstract}

Keywords: Hoax; Fake News; General Election; Democracy; Twitter.

\section{Introduction}

Since its arrival in 2006, Twitter has come to have an increasingly prominent role in the political communication process in many countries, including in Indonesia. Head of Business Development Twitter South East Asia and Australia, Dwi Ardiansyah said in the first quartar of 2017, world wide Twitter user reached 328 billion, an increase of 14 percent, compared to the same period the previous year. Indonesia is one of five countries in the world with a large number of Twitter users. During 2016, Indonesia had around 4,1 million Tweets produced by its 77 percent active Twitter users. Meanwhile, Indonesian internet users has reached 132,7 million or more than 50 percent of the total population $(256,2$ million) in which $97,5 \%$ of them consume social media, including Twitter. Twitter is a platform to talk about many topic like political, economic, environment and etc. Media also can brings hoax about environmental things also can effect political issue. For example, an issue about natural disaster that being used by political actors for their interest. Recently, This data shows that the internet will be continuously used by Indonesian people for political communication, today and in the future.

\section{Methodology}

Responding to the potential of the Internet in a democratization process, cyber-optimist undoubtfully said, "the Internet promotes better democratic practice". The thesis particularly based on reason that the internet facilitates interactive direct discussion between the elite and public, that guarantees freedom of speech. Gazali [1] an optimist in Indonesian political context, social media is a potential space for developing a digital democracy called 'social media democracy'. However, this study see Gazali's thesis irrelevant with the current setting of digital democracy in Indonesia, particularly in the context of political communication.

Rather than supporting the idea of cyber-optimists, this study tries to confirm it. By focussing on the discussion of new phenomena of hoax in Indonesian political context, this article will show how social media, particularly Twitter, used as a space for producing, distributing and consumming hoax and fakenews. In the last two years those terms have been a popular issue in the political area since they were used to win political contestation. Allcott \& Gentzkow who both do research about fake news during the 2016 USA precidential election, define fake news as news articles that are intentionally and verifiably false and could mislead readers[2]. In the USA presidential election for example, hoax and fake news were known as an influential determinant of Trump's election victory. Allcott \&

\footnotetext{
${ }^{*}$ Corresponding author: hedipudjos@gmail.com
} 
Gentzkow give an example of a hoax, it reported that Pope Francis had endorsed Donald Trump's presidential candidacy. The WTOE 5News "About" page disclosed it as "a fantasy news website. In Indonesian political context, Hasfi founded how hoaxes and fakenews were used by elites for mobilizing voters and for legitimating political power[3]. This study has an aim to explore about how hoax and fakenews produced during political contestation of the 2014 Indonesian general election. Who did produce and distribute them? And how the primordialism issue involved in the process.

\section{Discussion}

Hoax and fake news have a similar meaning that is used to describe false information. Although they have become widely used recently in online political discussion, there are no journal articles that provide a clear definition of both terms. Nonetheless, an article entitled 'Wabah Hoax' released by Tempo magazine (Januari 2-7, 2017) define them briefly. Both hoax and fake news are defined as misleading information. However they have significant differences. A Hoax is misleading information that refer to actual fact, meanwhile fake news is purely manipulative information that does not refer to any kind of facts. Based on those definitions, this study have identify some techniques of how hoaxes and fake newswere produced during the 2014 Indonesian Presidential Election and how they endanger Indonesian pluralism.

The study defines 'multi-contexts information' to describe how a single news item was used in many contexts for political gain. Critical discoures analysis show how this technique usually manipulates fact by using a past issue for constructing a new fact. One example was the use of Aljazeera's news report about Jokowi, who were reporting him as a populis transformative leader with a poor family backgroud. A Jokowi supporter Tweeted the news report and uploaded it to YouTube, with the new title 'Jokowi Hebohkan TV Al Jazeera'. The Tweet, defined as a hoax because it did not produce it in the context of Jokowi as presidential candidate of the 2014 general election, but it was produced in the context of Jokowi as Governoor of DKI Jakarta. In the perspective of critical discourse analysis this Tweet was used to construct Jokowi as good leader supported by the International media - in the perspective of Indonesia. Opinion from international media is an important element for legitimating leader's capacity. As the title of the news doesn't reflect the content of the story, this hoax also identified run under the clickbait technique - will be explained later. Secondly, another example of a hoax run under technique of multi context information was when Prabowo's supporter construct representation of Prabowo who were supported by the late Gus Dur. In this case, they used Gus Dur's statement, 'Prabowo is the most sincere person' (picture 2). The statement was played repeatedly on TVONE during dialog program 'Prabowo Bersama Rakyat'. The hoax went viral on social media, including Twitter a week before the 2014 election. The fact is, the late Gus Dur's statement was made in different context when he was interviwed by TVONE dialog program entitled 'Satu Jam Lebih Dekat' during the 2009 presidential election for endorsing PrabowoMegawati run in the 2009 Indonesian general election.

Another hoax with multi context information, was about the Tweet of Jokowi who was given Gus Dur's kopiah by Gus Dur's wife, Shinta Wahid . It looks as if Gus Dur's family supported Jokowi for president. The fact is the picture was taken on September $26^{\text {th }}, 2013$ at the commemoration of the $9^{\text {th }}$ Anniversary of Wahid Institue with the theme 'Spreading Peace and Protecting the Weak'. Jokowi was invited in the celebration as Governor of DKI, not as a candidate of Indonesian president. Comprehensive news articles was found at antaranews.com (26/09/2013) entitled 'Shinta give the late Gus Dur's Kopiah to Jokowi'. However the the news link was not attached onto the Twitter account thus reader did not get the whole story.

False attribution describes how information in which contains image, video, quote is being attributed to the wrong event. One of an example hoax that uses a false attribution techniqueis Picture. The picture 3 with caption 'PKI-KAN SAJA!!' was Tweeted by a pseudonym account Twitter @PartaiSocmed for encountering discourse of 'Jokowi communist' spreading widely on Twitter. 'PKI-kan saja' was known as a certain term used by Orde Baru for destroying their enemies including the communist. In this context, Jokowi's supporter produced the Tweet to construct Prabowo as part of the dictatorship regime, Orde Baru. The picture attached as if it was one of the brutalities during the era of elimination of the Indonesian Communist Party (PKI)1965-1966 conducted by Orde Baru. The fact is that the picture does not have any relations with the history of communism in Indonesia. The picture belongs to Neal Ulevich, an Associated Press (AP) journalist who won Pulitzer Prize in $1977^{2}$. The image captures a supporter of the military regime who stroke at the lifeless body of a left-wing student outside the Thammasat University during a demonstration against the return of the former military ruler, Thanom Kittikachorn.

Spoofing means to hoax, trick, or deceive. In the IT world, spoofing refers to tricking or deceiving computer systems or other computer users. This is typically done by hiding one's identity or by faking the identity of another user on the Internet. This study defines hoax spoofing as an act of creating hoax or fake news by tricking computer system thus a certain information appears illegaly on a certain websites or another computer device such us email, social media account, etc. In the context of 2014 Indonesian general election, spoofing hoax was identified in a Tweet distributed on the June $21^{\text {st }}, 2017$. The Tweet mentioned about statement of Ambassador of Palestine to Indonesia Fariz N. Mehdawi about the Palestineses who prayed for Jokowi's victory on 9 July 2014. The news was released by the Indonesian News Agency Antara for Sulawesi selatan, www.antara-sulawesiselatan.com. After the news article was released, there was many online mainstream media who distributed the information on the internet including on Twitter. However the information was identified as fake news. Chief Editor of LKBN 
Antara, Akhmad Kusaeni, clarified that portal www.antara-sulawesiselatan.com was spoofed by person who uploaded the news article as if it was quoting ambassador of Palestine to Indonesia Fariz. N. Mehdawi. The fact is there was no statements about writing such story either from Mehdawi and Antara. From the perspective of critical discourse analysis, the text was used for legitimating Palestine support for the candidates. Hasfi mentioned, in the context of Indonesian political leadership during the $2014^{\text {th }}$ election, Palestine's support for the candidates was a crucial criteria to define an ideal leadership for Indonesia[4]. However, the study has limitation in finding who and for whom the hoax spoofing was done for. Until this day, LKBN Antara does not uncover who was the spoocker.

It describes news article that uses eye-catching sensational title that usually does not reflect the content.This kind of hoax was dominating the political communication on Twitter during the election period. Previous tehniques which were explained earlier might be defined as hoax under this mechanism as they also have an inconsitency between its tittle and content. However, clickbait is focus more on the problem of how title of a news article created purposely for manipulating reader cognition and attention. The study identifies this technique that is involving a mainstream online media and uncredible online media that usually create sensational titles to attract readers. Twitter limits the length of its massages to only 140 characters and Twitter users are only focus on the titles rather than the content of the news article. For example, news article written on detik.com entitle 'Singgung Pencapresan Jokowi, Dubes Palestina: Rekam Jejaknya Bagus ${ }^{3}$ was used by @ PDI_Perjuangan for constructing Palestina's support for Jokowi. The Tweet was written as it was a proof that ambassador of Palestine endorsed Jokowi. The fact is that Ambassador of Palestine has neutral political statement in the news. In the last paragraft of the article, he clearly declared supports to all candidates who have a good quality of leadership.

Another hoax that used clickbait mechanism was found in a Tweet that was retweeted by @ gerindra linked with news article of an online media www.rmol.co (24/06/2014) entitled 'Dubes Palestina: Prabowo Pernah Nyumbang Rp 500 Juta Ketika Palestina Diinvasi Israel. The title of the article reflects as if it was quoting Ambassador of Palestine to Indonesia who said that Prabowo contributed 500 million rupiah for the Palestine during Soekarno Era. However, the body of the article explained that the statement of the Palestine's Ambassador was not exclusivelly addressed to Prabowo. The statement was dedicated to all Indonesian people particularly to the former president of Indonesia from Soekarno to SBY who helped the Palestine people during Israel invantion.

As discussed earlier, this study defines fake news as manipulative information that does not refer to any kind of facts.This study uncovers that fake news which was spreaded on Twitter was meant to attack both candidates, Jokowi particularly. The dominan fake news was found in many articles including 'Jokowi communist', 'Jokowi
Anthek China' and 'Jokowi Chinese Catholic'. Those fake news were generally produced and distributed strategically by two pseudonym Twitter accounts @TrioMacan2000 and @ pkspiyungan. @Triomacan2000 with its 700.000 followers produced the fake news of 'Jokowi communist' and 'Jokowi Anthek China' about 4 months before the election. In distributing the fake news, @TrioMacan2000 networked with many pseudonym Twitter accounts such us @burunghantu1913, @SiBinokiYo,@ @TheRoninWar, @ratu_adil, @ pribumi666, @kospirasiglobal and @m4ngu5il. They sistematically occupied the Twitter network because they have a big number of followers. However, this study uncovers that the fake news, which was produced by pseudonym Twitter accounts, never received many significant attention from mainstream media.

\section{Conclusion}

Firstly, based on the discussion above, this study concludes that hoax and fakenews were produced sistematically in the political communication during 2014th Indonesia presidential election. This study identifies hoaxes that run under some technique including 'multi-contexts information' in which a single news article was used in many contexts; 'false attribution' in which information may contain an image, video, quote attributed to the wrong event; 'hoax spoofing' in which information was produced by tricking a computer system, thus, certain information appears illegaly in spoofed websites, particularly credible websites; and clickbait in which a news article uses an eye catching sensational title that does not reflect the content.

Secondly, based on the identification of the actors who produce hoax and fake news, this study concludes that a hoax was commonly produced by an official Twitter account of a party who support candidates and voluntary's Twitter account of both candidate. The study also uncovered data about the production of the hoax and its involvement with online mainstream media by creating a sensational title for attracting readers. The Twitter account of both candidates commonly Tweeted misleading headlines created by mainstream online media to legitimize their discourse or to attack rival discourse. Meanwhile, this study reflects that fake news such us 'Jokowi Chatholic', 'Jokowi Communist' and 'Jokowi Anthek China' was generally produced by pseudonym Twitter accounts.

Thirdly, the content of hoax and fake news during 2014 Indonesia presidential election was identified by using issue of primordialism particularly based on religion and ethnicity. Based on the finding, the study concludes that fake news and hoax was produced to legitimate power of dominant ideology over minor ideology that harm diversity. This endangering democratization process since it creates unequality among society that might produce conflicts in the real setting. 


\section{References and Notes}

1. E. Gazali, Learning by clicking: An experiment with social media democracy in Indonesia International Communication Gazette (2014).

2. Allcott and G. Mattew, "Social Media and Fake News in the 2016 Election", J. Eco. Pers. , Vol. 31(2), pp. 211-236 (2017).

3. N. Hasfi, S. Usman, H. P. Santosa, Demokrasi Digital Dalam Media Sosial, Representasi JokowiPrabowo dalam Kontestasi Pemilu Presiden 2014 di Twitter, Retrieved from www.lib.ugm.ac.id on 27 August 2017 (2017a).

4. N. Hasfi, Representasi Kepemimpinan Calon Presiden di Twitter, J. Aspikom., Vol. 3(2) (2017b).

5. Balnaves \& Willson, A New Theory of Information and The Internet, Peter Lang, New York (2011).

6. A. Bruns, Habermas and against the Internet, Snurblog, Retrieved from http://snurb.info/node/621 on 7 October 2017 (2007).
7. J. A. G. M. Dijk, Digital Democracy: Vision and Reality, in I. Snellen \& W. van de Donk, Public Administration in the Information Age: Revisited, IOS- Press (2013).

8. R. S. Geiger, Does Habermas Understand the Internet? The Algorithmic Construction of the Blogo/Public Sphere, Gnovis: a J. Com. Cul. Tech, Vol. 1 (10) (2009).

9. T. O'Reilly, What is Web 2.0: Design patterns and business models for the next generation of software, $\quad$ Retrieved from http://oreilly.com/web2/archive/what-is-web20.html on 7 October 2017 (2005).

10. H. Rheingold, Habermas blows off question about the Internet and the Public Sphere, Smart Mobs, Retrieved from http://www.smartmobs.com/2007/11/05/habermas -blows-off-question-about-the-internet-and-thepublic-sphere/ on 13 October 2017 (2007).

11. R. D. Tsagarousianou, Electronic democracy: Rhetoric and reality, Communications: The Eu. J. Com, Res., Vol. 24 (2), pp. 189-208 (1999). 